\title{
Comparison of Radionuclide's Inventories and Activities with Slightly Enriched Uranium and Plutonium Fuel in CANDU Reactors
}

\author{
Zafar Yasin, Javaid Iqbal, M. Ikram Shahzad \\ Pakistan Institute of Engineering and Applied Sciences, P.O. Nilore, Islamabad, Pakistan \\ E-mail: yasinzf@yahoo.com, zyasin@cern.ch \\ Received March 22, 2011; revised May 3, 2011; accepted June 9, 2011
}

\begin{abstract}
In these studies the isotopic inventories and corresponding activities of important nuclides for different fuel cycles of a CANDU reactor have been compared. The calculations have been performed using the computer code WIMSD4. The isotopic inventories and activities have been calculated versus the fuel burn-up for the natural $\mathrm{UO}_{2}$ fuel, $1.2 \%$ enriched $\mathrm{UO}_{2}$ fuel and for the $0.45 \% \mathrm{PuO}_{2}-\mathrm{UO}_{2}$ fuel. It is found that $1.2 \%$ enriched uranium fuel has the lowest activity as compared to other two fuel cycles and vice versa for the $0.45 \%$ $\mathrm{PuO}_{2}-\mathrm{UO}_{2}$ fuel.
\end{abstract}

Keywords: Actinide and Fission Product Inventory, CANDU, Natural Uranium, Plutonium

\section{Introduction}

Due to many factors there is again an increase in trend to increase the contribution of nuclear energy, particularly in Asian countries [1,2], in the total world energy demand. The main drawback of nuclear energy is the radioactive waste, particularly spent nuclear fuel, and proliferation issue [2]. Management and handling of spent nuclear fuel and high level radioactive waste from nuclear reactors is a serious problem both from economical and environmental point of view. Shielding design for spent nuclear fuel, its transportation and storage, etc. depend on the activities of the nuclides present in the spent fuel, and these depend on the production of these nuclides during the fuel burn-up process. The more the concentration of these nuclides in the reactor core, the more decay heat these nuclei will produce in the spent fuel and more labours will be required to manage the spent fuel. Secondly, a large amount of plutonium is produced in the spent nuclear fuel, which can be easily separated from the fuel and can be used for military purpose. To overcome these two major concerns with the use of nuclear energy there are two options under consideration. Firstly, to change the composition of nuclear fuel that leads to higher burn-up, less production of plutonium and other minor actinides during burn-up and hence less amount of these nuclides in the spent fuel. Secondly, to entirely change the design of nuclear power reactors, like accelerator-driven systems (ADS) $[2,3]$.

In the present work, we are using the above said first option i.e. changing the fuel composition that leads to higher burn-up and less production of plutonium [1] and minor actinides. We are extending our previous study [1] and calculate the radioactive inventories and activities of important radionuclides during the reactor operation for the same three fuel cycles i.e. natural $\mathrm{UO}_{2}$ fuel, $1.2 \%$ enriched $\mathrm{UO}_{2}$ and $0.45 \% \mathrm{PuO}_{2}-\mathrm{UO}_{2}$ fuel. The above three fuel cycles are considered because these are recently used to study the burn-up extension and proliferation resistance potential with slightly enriched uranium and plutonium in CANDU reactors [1]. The use of slightly enriched uranium would reduce the quantity of spent fuel produced in CANDU reactors and have less environmental impact, compared to other fuel cycles.

Moreover, the above three fuel cycles are selected as the problem of spent fuel can be partially handled by increasing the fuel burn-up and it would reveal positive impact on the spent fuel characteristics [4], volume and decay heat per unit energy produced, and improve the environmental impact. It has been shown that with an increase of the burn-up upto 100 percent may reduce the plutonium production upto $35 \%$ [4]. A $1.2 \%$ enriched $\mathrm{UO}_{2}$ would increase the burn-up in CANDU by a factor of 3 and hence results in a smaller quantity of spent fuel production [5]. In our present study, with $1.2 \%$ enriched $\mathrm{UO}_{2}$ an increase in 
burn-up is observed by a factor of two [1]. Enrichment would also alleviate pressure on interim storage requirements at the reactor. With enrichment around $1.2 \%$, fuel cycle costs are lowered as compared to natural uranium fuel. Both front end and back end fuel cycle costs would be reduced. It has also been shown that with an enrichment between $0.9 \%$ to $1.2 \%$, there would be about $20 \%$ reduction in the total disposal cost as compared to natural $\mathrm{UO}_{2}$ [6] and $25 \%$ in reduction of uranium requirements can be achieved for enrichment between $0.9 \%$ to $1.2 \%$. Furthermore, plutonium recycling in the fuel, mixed with natural or depleted uranium, results in significant improvement in natural uranium utilization and proliferation resistance characteristics [7].

There are different possibilities under consideration to increase the fuel burn-up and reduction of radioactive waste. These include the use of PWRs spent fuel in CANDU reactors [8], use of slightly enriched uranium in CANDU reactors, use of small amount of Plutonium mixed with $\mathrm{UO}_{2}$ or mixed with $\mathrm{UO}_{2}-\mathrm{ThO}_{2}$, and $\mathrm{Th}-{ }^{233} \mathrm{U}$ fuel cycle [9-11].

The purpose of the present work is to calculate and compare the effect of slightly enriched uranium i.e. $1.2 \%$ enriched $\mathrm{UO}_{2}$ and $0.45 \%$ plutonium mixed $\left(80 \%{ }^{239} \mathrm{U}, 10 \%\right.$ ${ }^{240} \mathrm{Pu}$ and $10 \%{ }^{241} \mathrm{Pu}$ ) with $\mathrm{UO}_{2}$ on the activities of important isotopes during the fuel burn-up. The analysis is car- ried out using the computer code WIMSD4 (Winfrith Improved Multigroup Scheme version-D4) [12] for the CANDU $600 \mathrm{MW}_{\mathrm{e}}$ PHWR.

\section{Reactor Description}

There are 380 fuel channels in the standard CANDU 600 $\mathrm{MW}_{\mathrm{e}}$ reactor and each fuel channel contains 37-fuel pins. Figure 1 of [13] shows a cross sectional view of a fuel channels indicating a fuel bundle, a pressure tube, a calandria tube, and moderator. The coolant and moderator is $\mathrm{D}_{2} \mathrm{O}$. The heat is generated in the pressure tubes in the fuel bundle region and coolant transfers this heat to the power conversion system. A gemoterical representation of the cell and lattice benchmark cell model for WIMSD4 is shown in Figures 2 and 3, respectively, of [13]. The reactor data used to model the unit cell is given in Table 1 of [13]. The values of the radial and axial buckling are $4.1925 \mathrm{E}-5$ and $2.6870 \mathrm{E}-5$, respectively.

\section{Methodology}

The WIMSD4 (Winfrith Improved Multigroup Scheme version-D4) code is used to calculate the concentrations of important isotopes in the fuel bundle of the CANDU $600 \mathrm{MW}_{\mathrm{e}}$ reactor. WIMS-D4 is originally developed at Atomic Energy Establishment, Winfrith, UK. This code

Table 1 The values of inventories and corresponding activities of important fission products and actinides for the $\mathrm{UO}_{2}$ lattice at 16,000 MWD/te.

\begin{tabular}{ccccc}
\hline Nuclide & $\begin{array}{c}\text { Concentration } \\
\text { (Atoms) }\end{array}$ & $\begin{array}{c}\text { Half lives } \\
(s)\end{array}$ & Activity (Bq) & $\begin{array}{c}\text { Activity } \\
\text { (Ci) }\end{array}$ \\
\hline${ }^{235} \mathrm{U}$ & $2.19 \mathrm{E}+22$ & $2.22 \mathrm{E}+16$ & $6.82 \mathrm{E}+05$ & $1.84444 \mathrm{E}-05$ \\
${ }^{238} \mathrm{U}$ & $4.54 \mathrm{E}+25$ & $1.41 \mathrm{E}+17$ & $2.23 \mathrm{E}+08$ & 0.006034778 \\
${ }^{239} \mathrm{Pu}$ & $1.29 \mathrm{E}+23$ & $7.61 \mathrm{E}+11$ & $1.18 \mathrm{E}+11$ & 3.176119181 \\
${ }^{240} \mathrm{Pu}$ & $9.85 \mathrm{E}+22$ & $2.07 \mathrm{E}+11$ & $3.29 \mathrm{E}+11$ & 8.904084443 \\
${ }^{241} \mathrm{Pu}$ & $2.35 \mathrm{E}+22$ & $4.54 \mathrm{E}+08$ & $3.58 \mathrm{E}+13$ & 966.5856792 \\
${ }^{99} \mathrm{Tc}$ & $4.49 \mathrm{E}+22$ & $6.72 \mathrm{E}+12$ & $4.63 \mathrm{E}+09$ & 0.12520998 \\
${ }^{103} \mathrm{Ru}$ & $2.35 \mathrm{E}+22$ & $3.40 \mathrm{E}+06$ & $4.79 \mathrm{E}+15$ & 129561.4137 \\
${ }^{105} \mathrm{Rh}$ & $1.07 \mathrm{E}+20$ & $1.27 \mathrm{E}+05$ & $5.84 \mathrm{E}+14$ & 15789.74361 \\
${ }^{113} \mathrm{Cd}$ & $4.18 \mathrm{E}+18$ & $2.90 \mathrm{E}+23$ & $9.98 \mathrm{E}-06$ & $2.69676 \mathrm{E}-16$ \\
${ }^{115} \mathrm{In}$ & $1.13 \mathrm{E}+20$ & $1.61 \mathrm{E}+22$ & $4.87 \mathrm{E}-03$ & $1.31583 \mathrm{E}-13$ \\
${ }^{134} \mathrm{Cs}$ & $3.71 \mathrm{E}+21$ & $6.51 \mathrm{E}+07$ & $3.96 \mathrm{E}+13$ & 1069.29717 \\
${ }^{135} \mathrm{Xe}$ & $3.62 \mathrm{E}+18$ & $3.27 \mathrm{E}+04$ & $7.67 \mathrm{E}+13$ & 2071.808163 \\
${ }^{148} \mathrm{Pm}$ & $4.04 \mathrm{E}+19$ & $4.64 \mathrm{E}+05$ & $6.04 \mathrm{E}+13$ & 1631.799795 \\
${ }^{151} \mathrm{Sm}$ & $3.15 \mathrm{E}+20$ & $2.80 \mathrm{E}+09$ & $7.80 \mathrm{E}+10$ & 2.10861641 \\
${ }^{154} \mathrm{Eu}$ & $1.02 \mathrm{E}+21$ & $2.71 \mathrm{E}+08$ & $2.59 \mathrm{E}+12$ & 70.04903849 \\
${ }^{155} \mathrm{Eu}$ & $1.27 \mathrm{E}+20$ & $1.56 \mathrm{E}+08$ & $5.62 \mathrm{E}+11$ & 15.1809399 \\
\hline
\end{tabular}




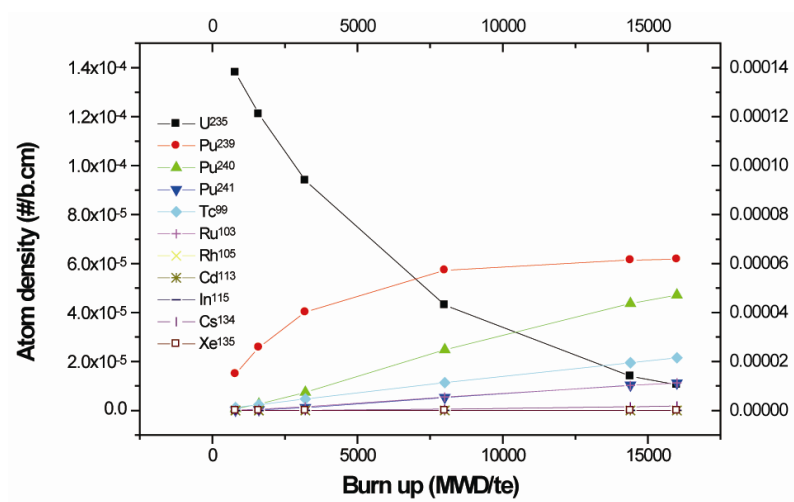

Figure 1. Atom density (\#/b.cm) of important isotopes as a function of burn-up for the natural $\mathrm{UO}_{2}$ fuel

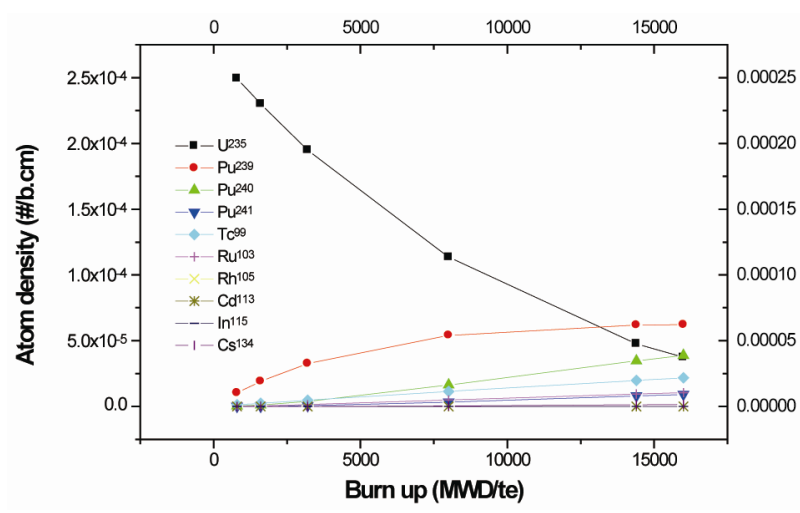

Figure 2. Atom density (\#/b.cm) of important isotopes as a function of burn-up for the $1.2 \%$ enriched $\mathrm{UO}_{2}$ fuel.

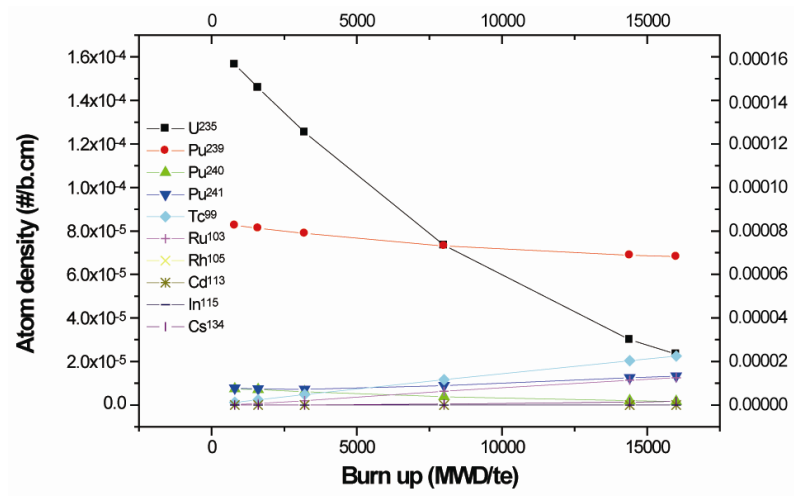

Figure 3. Atom density (\#/b.cm) of important isotopes as a function of burn-up for the $0.45 \% \mathrm{PuO}_{2}+$ natural $\mathrm{UO}_{2}$ fuel.

solves the one dimensional neutron transport theory for research and power reactors. The code can use different types of libraries available for analysis. For the analysis presented in this paper, 69 groups neutron cross section library of UK origin is used. The library of 69 groups consists of, 14 fast above $9.118 \mathrm{KeV}, 13$ resonances between $4 \mathrm{eV}-9.118 \mathrm{KeV}$ and 42 thermal groups below 4
$\mathrm{eV}$. For the present work, the 69 groups in the data set library are collapsed to five-group cross section data set. The boundaries of the energy shift of these five groups are given in Table 2 of [13]. This five group option is used in the FEWGROUP card.

This code takes the cluster geometry of the cell with the cards ANNULUS, ARRAY, and RODSUB. Sizes in the annulus card are selected in such a way that the fuel to coolant volume ratio is conserved and each fuel pin centre lies very close to the mid-radius of its ANNULUS. This can be achieved by using the CRAIG option. The cell-averaged diffusion coefficients (D), absorption $\left(\sum_{\mathrm{a}}\right)$, fission cross sections $\left(v \sum_{\mathrm{f}}\right)$, the infinite multiplication factor $\left(k_{\text {inf }}\right)$ and effective multiplication factor $\mathrm{k}_{\text {eff }}$ (if buckling is provided) can also be calculated by this code. For burn-up calculations, the code solves the burn-up equations for fuel and fission products for a given specific power and then calculates the isotopic compositions (\#/b.cm) and concentrations $(\mathrm{gm} / \mathrm{cm})$ of important isotopes present in the reactor core.

For burn-up calculations, power $\mathrm{C}$ card is needed in the input of WIMSD4 file. A number of sets of POWER cards are used in the input with one set of cards specifying a burn-up step. The ratio of power in $\mathrm{MW}_{\mathrm{t}}$ to the amount of initial fuel in tones is required for these cards. For the CANDU $600 \mathrm{MW}_{\mathrm{e}}$ case, this ratio is $25.06 \mathrm{MW} / \mathrm{te}$. The computer code WIMSD4 has already been used by us to model the pin type and cluster type geometries $[13,14]$.

\section{Results and Discussions}

These studies comprise of the calculations and comparison of the number densities (\#/b.cm) and activities (Ci), as a function of fuel burn-up, of important nuclides for alternative fuel cycles of the CANDU $600 \mathrm{MW}_{\mathrm{e}}$ PHWR. The number densities of important isotopes for natural $\mathrm{UO}_{2}$ fuel, $1.2 \%$ enriched $\mathrm{UO}_{2}$ and $0.45 \% \mathrm{PuO}_{2}-\mathrm{UO}_{2}$ fuel, are shown in Figures 1, 2 and 3, respectively. These three figures show a decrease in the concentration of ${ }^{235} \mathrm{U}$ with the burn-up that is due to the consumption of ${ }^{235} \mathrm{U}$. For the natural $\mathrm{UO}_{2}$ and $1.2 \%$ enriched $\mathrm{UO}_{2}$ fuel, there is an increase in the concentration of ${ }^{239} \mathrm{Pu}$ and other actinides and fission products and there is smaller increase in the amount of ${ }^{239} \mathrm{Pu}$ as compared to $\mathrm{UO}_{2}$ fuel and $0.45 \%$ $\mathrm{PuO}_{2}+\mathrm{UO}_{2}$ fuel. For $0.45 \% \mathrm{PuO}_{2}+\mathrm{UO}_{2}$ fuel, there is a slow decrease in the concentration of ${ }^{239} \mathrm{Pu}$, due to the ${ }^{239} \mathrm{Pu}$ already present in the core and second generation of ${ }^{239} \mathrm{Pu}$. Figures 1, 2 and $\mathbf{3}$ show that the nuclides ${ }^{235} \mathrm{U}$, ${ }^{239} \mathrm{Pu},{ }^{240} \mathrm{Pu},{ }^{241} \mathrm{Pu},{ }^{99} \mathrm{Tc},{ }^{135} \mathrm{Xe},{ }^{103} \mathrm{Ru}$, and ${ }^{134} \mathrm{Cs}$ have large concentration as compared to the other nuclides in the core. The activities are shown in Figures 4, 5, and 6 for natural $\mathrm{UO}_{2}$ fuel, $1.2 \%$ enriched $\mathrm{UO}_{2}$ and $0.45 \%$ 
Table 2 The values of inventories and corresponding activities of important fission products and actinides for the $1.2 \%$ enriched $\mathrm{UO}_{2}$ lattice at $16000 \mathrm{MWD} / \mathrm{te}$.

\begin{tabular}{|c|c|c|c|c|}
\hline Nuclide & $\begin{array}{c}\text { Concentration } \\
\text { (Atoms) }\end{array}$ & $\begin{array}{l}\text { Half lives } \\
\text { (s) }\end{array}$ & Activity (Bq) & $\begin{array}{l}\text { Activity } \\
\text { (Ci) }\end{array}$ \\
\hline${ }^{235} \mathrm{U}$ & $7.80 \mathrm{E}+22$ & $2.22 \mathrm{E}+16$ & $2.43 \mathrm{E}+06$ & $6.57395 \mathrm{E}-05$ \\
\hline${ }^{238} \mathrm{U}$ & $4.54 \mathrm{E}+25$ & $1.41 \mathrm{E}+17$ & $2.23 \mathrm{E}+08$ & 0.006028113 \\
\hline${ }^{239} \mathrm{Pu}$ & $1.30 \mathrm{E}+23$ & $7.61 \mathrm{E}+11$ & $1.19 \mathrm{E}+11$ & 3.203807422 \\
\hline${ }^{240} \mathrm{Pu}$ & $8.12 \mathrm{E}+22$ & $2.07 \mathrm{E}+11$ & $2.72 \mathrm{E}+11$ & 7.339771625 \\
\hline${ }^{241} \mathrm{Pu}$ & $1.91 \mathrm{E}+22$ & $4.54 \mathrm{E}+08$ & $2.91 \mathrm{E}+13$ & 786.8331462 \\
\hline${ }^{99} \mathrm{Tc}$ & $4.57 \mathrm{E}+22$ & $6.72 \mathrm{E}+12$ & $4.71 \mathrm{E}+09$ & 0.127355404 \\
\hline${ }^{103} \mathrm{Ru}$ & $2.21 \mathrm{E}+22$ & $3.40 \mathrm{E}+06$ & $4.50 \mathrm{E}+15$ & 121499.098 \\
\hline${ }^{105} \mathrm{Rh}$ & $9.48 \mathrm{E}+19$ & $1.27 \mathrm{E}+05$ & $5.16 \mathrm{E}+14$ & 13951.72382 \\
\hline${ }^{113} \mathrm{Cd}$ & $4.02 \mathrm{E}+18$ & $2.90 \mathrm{E}+23$ & $9.60 \mathrm{E}-06$ & $2.59562 \mathrm{E}-16$ \\
\hline${ }^{115} \mathrm{In}$ & $1.03 \mathrm{E}+20$ & $1.61 \mathrm{E}+22$ & $4.43 \mathrm{E}-03$ & $1.19838 \mathrm{E}-13$ \\
\hline${ }^{134} \mathrm{Cs}$ & $3.15 \mathrm{E}+21$ & $6.51 \mathrm{E}+07$ & $3.35 \mathrm{E}+13$ & 906.62775 \\
\hline${ }^{135} \mathrm{Xe}$ & $4.08 \mathrm{E}+18$ & $3.27 \mathrm{E}+04$ & $8.65 E+13$ & 2336.663542 \\
\hline${ }^{148} \mathrm{Pm}$ & $4.54 \mathrm{E}+19$ & $4.64 \mathrm{E}+05$ & $6.78 \mathrm{E}+13$ & 1831.8187 \\
\hline${ }^{151} \mathrm{Sm}$ & $3.23 \mathrm{E}+20$ & $2.80 \mathrm{E}+09$ & $7.99 \mathrm{E}+10$ & 2.159803888 \\
\hline${ }^{154} \mathrm{Eu}$ & $8.21 \mathrm{E}+20$ & $2.71 \mathrm{E}+08$ & $2.10 \mathrm{E}+12$ & 56.68217904 \\
\hline${ }^{155} \mathrm{Eu}$ & $1.05 \mathrm{E}+20$ & $1.56 \mathrm{E}+08$ & $4.65 \mathrm{E}+11$ & 12.57420794 \\
\hline
\end{tabular}

$\mathrm{PuO}_{2}-\mathrm{UO}_{2}$ fuel, respectively. From the Figures 4, 5, and 6 it is seen that the nuclides ${ }^{103} \mathrm{Ru},{ }^{105} \mathrm{Rh},{ }^{135} \mathrm{Xe},{ }^{137} \mathrm{Cs}$, ${ }^{241} \mathrm{Pu},{ }^{134} \mathrm{Cs},{ }^{151} \mathrm{Sm},{ }^{154} \mathrm{Eu},{ }^{241} \mathrm{Pu},{ }^{240} \mathrm{Pu}$ and ${ }^{239} \mathrm{Pu}$ have more activity as compared to other nuclides in the reactor core. The Figures also show that the nuclides produced in the $1.2 \%$ enriched $\mathrm{UO}_{2}$ fuel have the lower activities as compared to the other two fuel cycles and vice versa for the $0.45 \% \mathrm{PuO}_{2}+\mathrm{UO}_{2}$ fuel. This means that from the environmental point of view, $1.2 \%$ enriched $\mathrm{UO}_{2}$ fuel is more useful in CANDU reactors as compared to natural uranium fuel and the fuel in which Plutonium is mixed with natural uranium. Plutonium mixed with natural uranium has more contribution of these nuclides and hence not a better choice from environmental point of view but it can be used to extend the fuel burn-up and to burn the large stocks of civil and military plutonium [10]. Moreover, there is a general trend to reduce the plutonium because of the serious public and political concerns in the world about the misuse of plutonium or accidental release into the environment [10]. Thorium mixed with $\mathrm{UO}_{2}$ or $\mathrm{PuO}_{2}$ is a better fuel composition from environmental and proliferation perspectives but it can be beneficial for a country that has lot of thorium reserves, like In- dia.

The sum of the activities (in Curie) of important isotopes as a function of burn-up for natural $\mathrm{UO}_{2}$ fuel, $1.2 \%$ enriched $\mathrm{UO}_{2}$ and $0.45 \% \mathrm{PuO}_{2}-\mathrm{UO}_{2}$ fuel, is shown in Figure 7. In the three cases, there is a linear increase in activity with the burn-up and the $1.2 \%$ enriched $\mathrm{UO}_{2}$ fuel has the lowest activity as compared to other two fuel cycles and vice versa for the $0.45 \% \mathrm{PuO}_{2}+\mathrm{UO}_{2}$ fuel. Hence, from environmental aspect, $1.2 \%$ enriched $\mathrm{UO}_{2}$ fuel is more useful in CANDU reactors as compared to natural uranium fuel and the fuel in which Plutonium is mixed with natural uranium. Consequently, again, from environmental point of view plutonium mixed in natural $\mathrm{UO}_{2}$ is not a better choice but it can be used to extend the fuel burn-up and to destroy the huge quantity of plutonium in the world. Thorium mixed with $\mathrm{UO}_{2}$ or $\mathrm{PuO}_{2}$ is a better fuel composition from environmental and proliferation perspectives.

The inventory and activity (in Becquerel and in Curie) of important isotopes calculated at $16,000 \mathrm{MWD} /$ te for the three fuel cycles i.e. natural $\mathrm{UO}_{2}, 1.2 \%$ enriched $\mathrm{UO}_{2}$ and $0.45 \% \mathrm{PuO}_{2}+\mathrm{UO}_{2}$ are shown in Tables 1, 2 and 3, respectively. From these tables, the major contribution to 


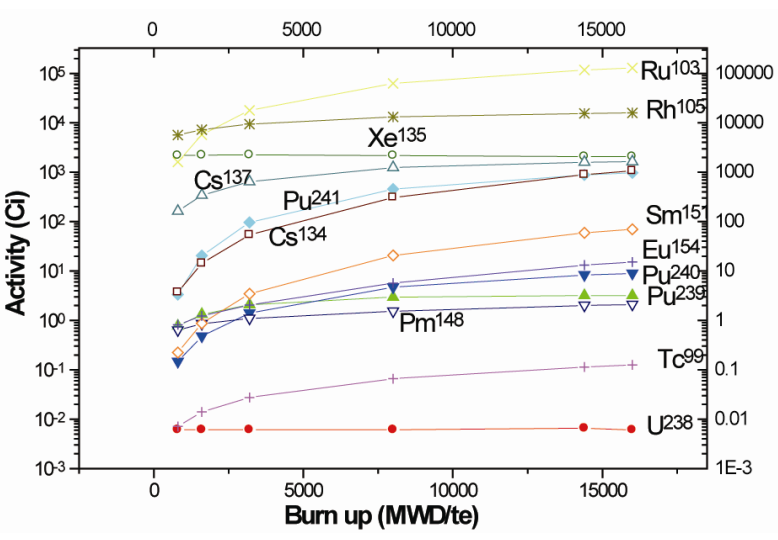

Figure 4 Activities (Ci) of important isotopes as a function of burn-up for the natural $\mathrm{UO}_{2}$ fuel.

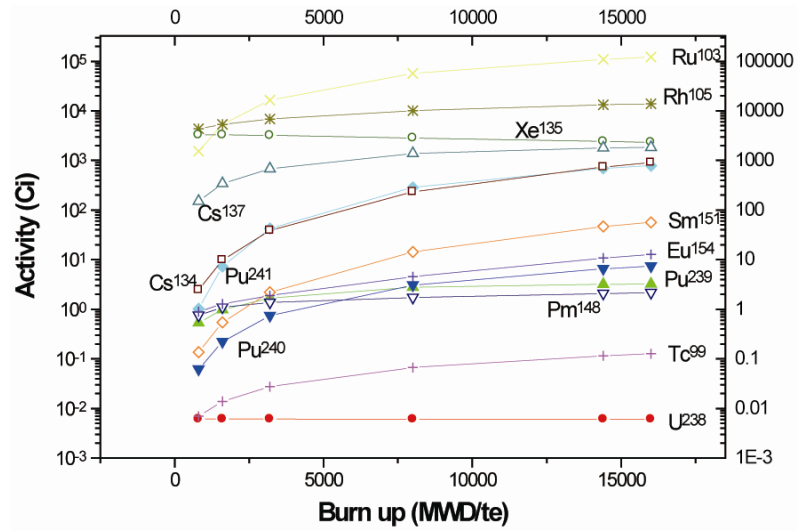

Figure 5 Activities (Ci) of important isotopes as a function of burn-up for the $1.2 \%$ enriched $\mathrm{UO}_{2}$ fuel.

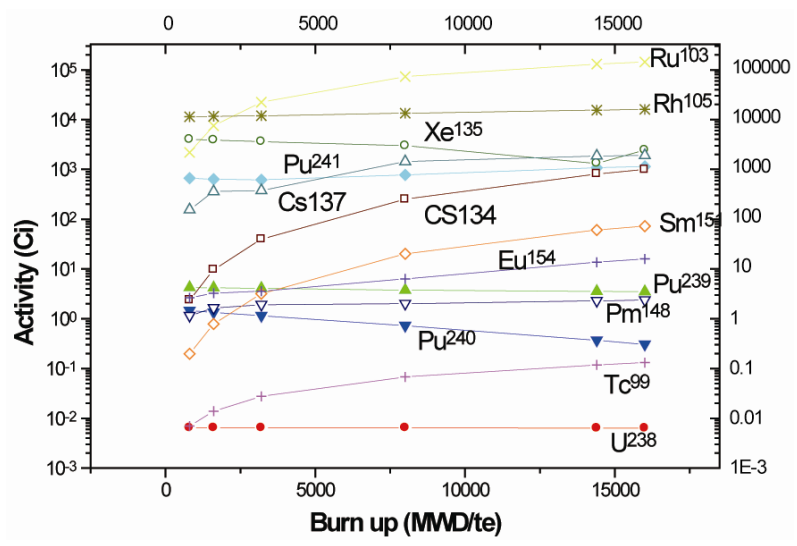

Figure 6 Activities (Ci) of important isotopes as a function of burn-up for the $0.45 \% \mathrm{PuO}_{2}$ +natural $\mathrm{UO}_{2}$ fuel.

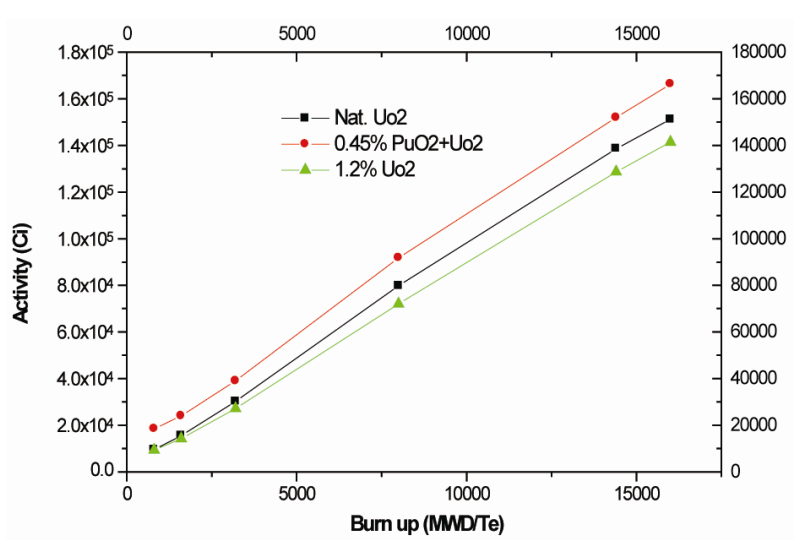

Figure 7. Total activities (Ci) of important isotopes as a function of burn-up for the natural $\mathrm{UO}_{2}, 1.2 \%$ enriched $\mathrm{UO}_{2}$, and $0.45 \% \mathrm{PuO}_{2}+$ natural $\mathrm{UO}_{2}$ fuel.

Table 3 The values of inventories and activities of fission products and actinides for the $0.45 \% \mathrm{PuO}_{2}+\mathrm{UO}_{2}$ lattice at 16,000 MWD/te.

\begin{tabular}{ccccc}
\hline Nuclide & $\begin{array}{c}\text { Concentration } \\
\text { (Atoms) }\end{array}$ & $\begin{array}{c}\text { Half lives } \\
(\mathrm{s})\end{array}$ & $\begin{array}{c}\text { Activity } \\
(\mathrm{Bq})\end{array}$ & $\begin{array}{c}\text { Activity } \\
(\mathrm{Ci})\end{array}$ \\
\hline${ }^{235} \mathrm{U}$ & $4.89 \mathrm{E}+22$ & $2.22 \mathrm{E}+16$ & $1.53 \mathrm{E}+06$ & $4.1228 \mathrm{E}-05$ \\
${ }^{238} \mathrm{U}$ & $4.77 \mathrm{E}+25$ & $1.41 \mathrm{E}+17$ & $2.35 \mathrm{E}+08$ & 0.006341391 \\
${ }^{239} \mathrm{Pu}$ & $1.43 \mathrm{E}+23$ & $7.61 \mathrm{E}+11$ & $1.30 \mathrm{E}+11$ & 3.511208658 \\
${ }^{240} \mathrm{Pu}$ & $3.39 \mathrm{E}+21$ & $2.07 \mathrm{E}+11$ & $1.13 \mathrm{E}+10$ & 0.306584891 \\
${ }^{241} \mathrm{Pu}$ & $2.78 \mathrm{E}+22$ & $4.54 \mathrm{E}+08$ & $4.23 \mathrm{E}+13$ & 1143.856252 \\
${ }^{99} \mathrm{Tc}$ & $4.70 \mathrm{E}+22$ & $6.72 \mathrm{E}+12$ & $4.85 \mathrm{E}+09$ & 0.131051597 \\
${ }^{103} \mathrm{Ru}$ & $2.61 \mathrm{E}+22$ & $3.40 \mathrm{E}+06$ & $5.32 \mathrm{E}+15$ & 143762.607 \\
${ }^{105} \mathrm{Rh}$ & $1.09 \mathrm{E}+20$ & $1.27 \mathrm{E}+05$ & $5.92 \mathrm{E}+14$ & 15991.84889 \\
${ }^{113} \mathrm{Cd}$ & $4.81 \mathrm{E}+18$ & $2.90 \mathrm{E}+23$ & $1.15 \mathrm{E}-05$ & $3.10956 \mathrm{E}-16$ \\
${ }^{115} \mathrm{In}$ & $1.26 \mathrm{E}+20$ & $1.61 \mathrm{E}+22$ & $5.44 \mathrm{E}-03$ & $1.46941 \mathrm{E}-13$ \\
${ }^{134} \mathrm{Cs}$ & $3.44 \mathrm{E}+21$ & $6.51 \mathrm{E}+07$ & $3.66 \mathrm{E}+13$ & 989.1961717 \\
${ }^{135} \mathrm{Xe}$ & $4.28 \mathrm{E}+18$ & $3.27 \mathrm{E}+04$ & $9.07 \mathrm{E}+13$ & 2452.395648 \\
${ }^{148} \mathrm{Pm}$ & $4.71 \mathrm{E}+19$ & $4.64 \mathrm{E}+05$ & $7.03 \mathrm{E}+13$ & 1900.517176 \\
${ }^{151} \mathrm{Sm}$ & $3.53 \mathrm{E}+20$ & $2.80 \mathrm{E}+09$ & $8.74 \mathrm{E}+10$ & 2.363015378 \\
${ }^{154} \mathrm{Eu}$ & $1.05 \mathrm{E}+21$ & $2.71 \mathrm{E}+08$ & $2.67 \mathrm{E}+12$ & 72.16286072 \\
${ }^{155} \mathrm{Eu}$ & $1.32 \mathrm{E}+20$ & $1.56 \mathrm{E}+08$ & $5.87 \mathrm{E}+11$ & 15.86223062 \\
\hline
\end{tabular}


the total activity is from the nuclides ${ }^{241} \mathrm{Pu},{ }^{103} \mathrm{Ru}$, ${ }^{105} \mathrm{Rh},{ }^{134} \mathrm{Cs},{ }^{135} \mathrm{Xe}$ and ${ }^{148} \mathrm{Pm}$. In natural $\mathrm{UO}_{2}$ fuel and in $0.45 \% \mathrm{PuO}_{2}+\mathrm{UO}_{2}$ fuel these isotopes have more contribution and hence lead to more activity as compared to $1.2 \%$ enriched $\mathrm{UO}_{2}$ fuel that has least activity.

In case of $1.2 \%$ enriched $\mathrm{UO}_{2}$ fuel, more neutrons are absorbed in ${ }^{235} \mathrm{U}$ as compared to natural $\mathrm{UO}_{2}$ and $0.45 \%$ $\mathrm{PuO}_{2}+\mathrm{UO}_{2}$ fuel. The reason for more activity in $\mathrm{UO}_{2}$ and $0.45 \% \mathrm{PuO}_{2}$ is the more fission in ${ }^{239} \mathrm{Pu}$ as compared to fission in ${ }^{235} \mathrm{U}$.

\section{Conclusions}

The results presented in the present paper comprise of calculations and comparison of the effect of slightly enriched uranium i.e. $1.2 \%$ enriched $\mathrm{UO}_{2}$ and $0.45 \% \mathrm{PuO}_{2}$ $+\mathrm{UO}_{2}$ with the activities of important isotopes during the fuel burn-up. The results are presented in the form of figures. The conclusion of three fuel cycles considered in the present work is; the activity of $1.2 \%$ enriched $\mathrm{UO}_{2}$ fuel is much smaller as compared to natural $\mathrm{UO}_{2}$ fuel and plutonium mixed in $\mathrm{UO}_{2}$ fuel. Secondly, the slightly enriched $\mathrm{UO}_{2}$ fuel will make radioactive waste management more effective and have less environmental impact, compared with other two fuel cycles.

\section{References}

[1] Z. Yasin, "Burn-up Extension with Slightly Enriched Uranium and Plutonium in CANDU Reactors," Nuclear Engineering and Design, Vol. 240, No. 10, 2010, pp. 2862-2865. doi:10.1016/j.nucengdes.2010.05.068

[2] Z. Yasin and M. I. Shahzad, "From Conventional Nuclear Power Reactors to Accelerator-Driven Systems," Annals of Nuclear Energy, Vol. 37, No. 2, 2010, pp. 87-92. doi:10.1016/j.anucene.2009.11.003

[3] C. Rubbia, et al., "Conceptual Design of a Fast Neutron
Operated High Power Energy Amplifier," CERN/AT/9544 (ET), 29 September 1995.

[4] Z. Xu, "Design Strategies for Optimizing High Burn-up Fuel in Pressurized Water Reactors," Ph.D Thesis, Massachusetts Institute of Technology, Cambridge, 2000.

[5] D. F. Torgerson, P. G. Boczar and A. R. Dastur, "CANDU Fuel Cycle Flexibility," 9th Pacific Basin $\mathrm{Nu}$ clear Conference, Sydney, 1-4 May 1994.

[6] OECD/NEA, "The Economics of the Nuclear Fuel Cycle," OECD/NEA Report, 1994.

[7] B. Pellaud, "Proliferation Aspects of Plutonium Recycling," Comptes Rendus Physique, Vol. 3, No. 7, 2002, pp. 1067-1079. doi:10.1016/S1631-0705(02)01364-6

[8] P. Jee-Won, "A Subchannel Analysis of DUPIC Fuel Bundle for the CANDU Reactor," Annals of Nuclear Energy, Vol. 26, No. 1, 1999, pp. 29-46. doi:10.1016/S0306-4549(98)00028-0

[9] S. Sahin, et al., "Power Flattening in the Fuel Bundle of a CANDU Reactor," Nuclear Engineering and Design, Vol. 232, No. 1, 2004, pp. 07-11

[10] S. Sahin, et al., "An Assessment of Thorium and Spent LWR-Fuel Utilization Potential in CANDU Reactors," Energy Conversion and Management, Vol. 47, No. 13-14, 2006, pp. 1661-1675. doi:10.1016/j.enconman.2005.10.013

[11] H. P. Gupta, et al., "Advanced Fuel Cycles for Use in PHWRs," Journal of Nuclear Materials, Vol. 383, No. 1-2, 2008, pp. 54-62.

[12] M. J. Halsall, "Summary of WIMSD4 Input Options," AEEW-M 1327, Dorchester, 1980.

[13] Z. Yasin, "Calculation of Fuel Burn-up and Radioactive Inventory in a CANDU Reactor Using WIMSD4 Code," Annals of Nuclear Energy, Vol. 37, No. 1, 2010, pp. 87-92. doi:10.1016/j.anucene.2009.11.003

[14] Z. Yasin, "Comparative Study of Fuel Burn-up and Radioactive Inventory for Proliferation and Proliferation Resistance Fuel Lattices," Annals of Nuclear Energy, Vol. 36, No. 9, 2009, pp. 1635-1638. doi:10.1016/j.anucene.2009.08.004 